\title{
Milk producer's articulation: a multicast study in Córdoba, Colombia
}

\section{Articulación de productores de leche: un estudio multicaso en Córdoba, Colombia Articulação de produtores de leite: um estudo multicast em Córdoba, Colômbia}

\author{
Elvira Durán-Rojas ${ }^{\mathrm{a}^{*}} \mid$ Paula Judith Pérez Espitia ${ }^{\mathrm{b}}$ Omar Andrés Pérez-Sierra ${ }^{\mathrm{c}}$

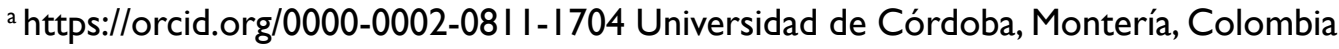 \\ ${ }^{b}$ https://orcid.org/0000-000 I-6262-0852 Universidad del Atlántico, Puerto Colombia, Colombia \\ c https://orcid.org/0000-0002-0749-7967 Universidad de Córdoba, Montería, Colombia
}

- Fecha de recepción: 2019-08-30

- Fecha concepto de evaluación: 2019-10-13

- Fecha de aprobación: 2019-11-13 http://dx.doi.org//0.22335/rlct.vI2il.1020
Para citar este artículo / To reference this article / Para citar este artigo: DuránRojas, E., Pérez Espitia, P.J., \& Pérez-Sierra, O.A. (2020). Milk producer's articulation: a multicast study in Córdoba, Colombia. Revista Logos Ciencia \& Tecnología, I2(I), II0-120. http://dx.doi. org/I0.22335/rlct.vI2il.1020

\begin{abstract}
SUMMARY
Objective: To characterize the articulation of milk producers in Córdoba, Colombia. Methods: Descriptive multicast study composed of II producers and a dairy cooperative. Surveys and an interview were applied, the information was analyzed using descriptive statistics and content analysis. Results: The dairy cooperative within the production chain performs: milk collection $(70 \%$ comes from associates), processing and marketing. The purchase criterion is to deliver the milk at low temperature to minimize risks. This contributes to the producer in receiving a benefit in the price of the product. Most dairy farms are medium-sized; they produce milk on average of $4.8 \mathrm{~L} / \mathrm{cow} /$ day, whose price received in the market varies from US $\$ 0.32$ / L to US $\$ 0.47$ / L.Vertical articulation is carried out between producers, processing companies and the cooperative where they receive support in technical and financial assistance; horizontal articulation based on alliances between producers to collect milk in cold tank. Conclusions: There are few producers associated with a cooperative for a better articulation within the value chain, although more than half commercialize milk in formal markets prevents them from enjoying the benefits of being in a solidarity organization.
\end{abstract}

Keywords: productive alliance, food chain, competitiveness, dairy, relationship

*Autor para correspondencia. Correo electrónico: edrojas@correo.unicordoba.edu.co 


\begin{abstract}
RESUMEN
Objetivo: Caracterizar la articulación de productores de leche en Córdoba, Colombia. Métodos: Estudio descriptivo multicaso descriptivo compuesto por II productores y una cooperativa lechera. Se aplicaron encuestas y una entrevista, se analizó la información mediante estadística descriptiva y análisis de contenido. Resultados: La cooperativa lechera dentro de la cadena productiva realiza: acopio ( $70 \%$ proviene de asociados), procesamiento y comercialización. El criterio de compra es entregar la leche fría para minimizar riesgos y contribuye al productor en recibir beneficio en el precio del producto. La mayoría de las fincas lecheras son de tipo de mediana; producen leche en promedio de $4,8 \mathrm{~L} / \mathrm{vaca} /$ día, cuyo precio recibido en el mercado es de US $\$ 0,32 / \mathrm{L}$ a US $\$ 0.47 / \mathrm{L}$. La articulación vertical se realiza entre los productores, las empresas de procesamiento y la cooperativa donde reciben apoyo en asistencia técnica y financiera; articulación horizontal basada en alianzas entre los productores para acopiar la leche en tanque frío. Conclusiones: Son pocos los productores asociados a una cooperativa para una mejor articulación dentro de la cadena valor, a pesar de que más de la mitad comercializa la leche en mercados formales les impide de cierta forma gozar de los beneficios que ofrece estar en una organización solidaria.
\end{abstract}

Palabras clave: alianza productiva, cadena de alimentos, competitividad, lechería, relacionamiento

\title{
SUMÁRIO
}

Objetivo: Caracterizar a articulação dos produtores de leite em Córdoba, Colômbia. Métodos: Estudo descritivo multicast descritivo, composto por II produtores e uma cooperativa de laticínios. Foram aplicadas pesquisas e entrevista, as informações foram analisadas por meio de estatística descritiva e análise de conteúdo. Resultados: A cooperativa de laticínios da cadeia produtiva realiza: coleta $(70 \%$ de associados), processamento e comercialização. $O$ critério de compra é entregar o leite frio para minimizar riscos e contribuir para que o produtor receba benefício no preço do produto. A maioria das fazendas leiteiras é de tamanho médio; eles produzem leite em média 4,8 L / vaca / dia, cujo preço recebido no mercado é de US $\$ 0,32$ / L a US $\$ 0,47$ / L.A articulação vertical é realizada entre produtores, empresas de processamento e a cooperativa, onde recebem apoio na assistência técnica e financeira; articulação horizontal baseada em alianças entre produtores para coletar leite em tanque frio. Conclusões: Existem poucos produtores associados a uma cooperativa para uma melhor articulação dentro da cadeia de valor, embora mais da metade comercialize leite em mercados formais os impeça de usufruir dos benefícios de pertencer a uma organização solidária.

Palavras-chave: aliança produtiva, cadeia alimentar, competitividade, laticínios, relacionamento

The food supply chain is defined as a series of companies that articulate and interact closely in order to produce goods and/or services with a high quality at the lowest cost possible; the food supply chain involves the food and agricultural value chain (Govindan, 2018).

In Colombia, there are almost 400,000 milk producers, mostly small and medium-sized cattle ranchers (Ministerio de Agricultura y Desarrollo Rural [Minagricultura], 20I5), either under specialized production (specifically for milk production) or as a dual-purpose system (Asociación Colombiana de Procesadores de Leche [ASOLECHE], 20I0).
Córdoba is one of the seven departments which constitute the Caribbean Region of Colombia. It has more than $55 \%$ of the national bovine herd (Consejo Nacional de Política Económica y Socia [CONPES], 2005), having the seventh position within the top 10 departments of milk production in Colombia (Minagricultura, 2010). Although some farmers, cooperatives and the milk processing in this area have made efforts to achieve a significant growth in this business, there is a low milk processing, with only $36.5 \%$ of the total milk produced in this department being formally processed. This indicates that the milk commercialization is still mainly informal and this situation persists 
due to the limited capacity of the milk processing industry, which is unable to transform most of the supplied milk (Albor, 20II).

Moreover, around 500,000 L of milk are sold daily through an informal channel due to the ease of its commercialization, the lack of control by the authorities and the culture towards the preference for the consumption of raw milk. In this regard, the milk that is traded informally cannot be used in the dairy industry, because it does not meet the minimum quality requirements established (Ministerio de Salud y Protección Social [Minsalud], 20II).

The poor associativity or organization of rural producers in Colombia and their well-known aversion to the formal or legal business (which is linked to increased costs) is a limiting factor for the development of vertical alliances or inclusive businesses (Centro Internacional de Agricultura Tropical [CIAT], 2007). In Colombia, milk cooperatives are institutions aiming to facilitate business between farmers and the dairy industry, being considered as intermediaries in the milk production chain (Tordecilla-Madera et al., 2017). The producer's link to the cooperative ensures the purchase of inputs and the sale of milk at an adequate market price, as well as better access to financing, technical assistance services and agreements. The cooperative is a strategic organization to potentiate the negotiating power of the producers, to improve the quality and productivity of the milk and have access to the different services of their area of activity, ensuring the flow of the product in the market with a consolidated brand (De Sousa, 2017); this ensures the advantages of vertical integration (Zylbersztajn, 1994), such as the acquisition of inputs (López and Peña, 20I6), own production of balanced food and alliances to strengthen their production (Craviotti, 2019). In this regard, milk processing and marketing in the department of Córdoba is done by two cooperatives and by a milk processing company.

Therefore, there is a need for collaboration among these economic actors, specifically oriented to the generation of a competitive advantage, known as productive articulation (Dini, 2010; Ferraro, 2010). Business articulation allows increasing the collective efficiency from repetitive interactions based on the knowledge, learning, and development of new technologies (Vera \& Ganga, 2007). These collaborative interactions take place in both ways, horizontal and vertical; vertical articulation is done among stakeholders that are part of the same productivity chain; an example of this is the articulation among suppliers, manufacturers, and distributors. On the other hand, the horizontal articulation takes place among different stakeholders which develop activities in the same area, producing similar goods or services (Alburquerque \& Dini, 2008; Dini et al., 2006). On the other hand, inside each articulation, vertical clusters are constituted by industries characterized by a relationship determined by buying and selling activities; while horizontal clusters include companies that are characterized by sharing a common market to their final products or services, by using the same technology or work labor, or by requiring a similar natural resource (Porter, 1998, 2003).

At the international level, it has been reported that in places like Kenya, Africa, most of the smallholders are characterized by a production for subsistence, while commercialized production is hard to achieve. Some of the reasons of this include the high cost related with transaction, lack of or limited service regarding technology, advisory, transportation, among others. Thus, one of the alternative strategies to overcome these drawbacks consist on the organization of the smallholder collective actions through their articulation with other stakeholders in the agrifood value chain (Kilelu et al 2017).

In Latin America, there are some cases of special interest in this topic. In this regard, the Brazilian dairy industry has been characterized by an impressive growth, primarily developed in the "Grande Fronteira do Mercosul (GFM)" area (South Brazil), being its production based on smallholders and cooperatives. Thus, the dairy value chain represents high importance in the societal and economical field. However, the development of this agrifood value chain has been limited when compared to other sectors in Brazil, such as beef, soybean, maize, pork, sugarcane among others. In this regard, the articulation (vertical and horizontal) among the stakeholders of this value chain is one of the key aspects that affect its competitiveness (Beber et al., 2019).

Although the department of Córdoba stands out in the Caribbean Region of Colombia due to its dairy production, few primary producers are associated and articulated in the formal and legal sector, which prevents them from reaching competitively new markets. In addition, the articulation characteristics of dairy producers, cooperatives, associations, processing and marketing companies are unknown in the department of Córdoba. 
This study aimed to evaluate the existent arrangement of business articulation between primary milk producers and a milk processing cooperative in the department of Córdoba. Moreover, this study constitutes a baseline to determine the relationship among the different actors in the milk production chain, their advantages, and disadvantages, which will allow the development of strategies that promote the milk agribusiness competitiveness and sustainability.

\section{Materials and methods}

This research was a multicase descriptive study based on I I dairy producers from the middle Sinú region of the department of Córdoba, Colombia to whom a semi-structured survey was applied and the manager of a dairy cooperative of the department of Córdoba to whom an interview was conducted. For the selection of the II milk producers, the snowball sampling was taken into account (Casal \& Mateu, 2003); this was the most appropriate, since it allowed the identification of the milk producers more easily. In this regard, most of the farms which were participating in this study worked with dual purpose system (production of meat and milk simultaneously).

In order to collect primary information, an in-depth interview was conducted to the manager of the dairy cooperative regarding social, production, and marketing, as well as management aspects. A semi-structured survey was applied to the owners and/or managers of the selected farms regarding the social, production and administration aspects. Each milk producer was coded consecutively from I to II and for this study, they were classified according to the size of the farm destined for milk production (CONPES, 2005). Among the analyzed variables, milk production, milk price, relationship, technical advice, process standardization, service exchange and strategic alliances were taken into account.

Interviews were recorded and the information was analyzed using the content analysis method. The information obtained from the surveys was tabulated and analyzed run with Microsoft Excel ${ }^{\circledR}$ using descriptive statistics.

\section{Results and discussion}

\section{Cooperative characterization}

The milk cooperative studied was constituted more than 20 years ago, and it had more than 60 associates, which were milk producers. The milk cooperative is responsible for collecting the milk produced in the department of Córdoba, processing, and marketing it.

The main dairy products obtained are UHT milk and flavored milk. Sometimes, the milk surplus obtained during the winter season resulted in the production of powdered milk. The powder milk production is usually done at a small scale, and for a limited period of time, because there is a required investment which limits the expansion of the powder milk production capacity.

The milk cooperative has trained workers in different fields of knowledge, such as food engineer, microbiologists, and technicians, for the proper functioning of the milk processing and transformation, which comply with the professional and technical skills to control the quality of the product. The milk supply is mixed, $70 \%$ comes from associates and $30 \%$ from independent producers.

In this regard, the number of milk suppliers was reduced from 320 that supplied from 70,000 to $80,000 \mathrm{~L} /$ day to 240 with a production of $30,000 \mathrm{~L} /$ day. This reduction resulted from the instability of prices due to the cyclical effect of winter and summer (supply and demand), to the entry of milk quotas negotiated under the free trade agreements, and due to unfair competition, such as smuggling and whey marketing (most of the time sold as milk), among other limiting factors. Thus, this situation led the cooperative to analyze those factors and to decide to implement the Ultra High Temperature (UHT) processing at a low scale.

\section{Characterization of milk producers: \\ Size of the milk production}

The organizational structure possessed by the dairy production farms studied are very similar (agricultural producer-engineer / veterinary doctor and zootechnist-manager-workers), except for 4 farms that have accounting advice that allows them to keep simple records for their financial organization. These farms have a staff of 2 to 15 workers, a figure that depends on their size. Taking into account that in the study region the production is dual purpose (meat and milk), most of the farms $(8 / \mathrm{II})$ have all their workers for the dairy activity and have a worker in charge to perform functions as administrator, when the owner is not present. Although the majority $(9 / \mathrm{II})$ of the owners are professionals and visit the farm on a daily basis and during the week (I0/II), more than half $(6 / \mathrm{II})$ of those in charge of the farms have 
a basic schooling and the remaining $(5 / \mathrm{II})$ secondary level, which can be considered as a weakness in the administration and in the implementation of the technification processes when the owner is not in the farm.

According to CONPES (2005), the size of dairy production might vary considering the number of milking cows that the primary producers own. In this regard, the dairy production is small when they have from I to 20 cows, medium size when the farm has from 21 to 100 cows and large when there are more than 100 cows in the farm. In this study, $8 / 1$ I of the milk farms were classified as medium size. It is worth clarifying, that for this classification only those cows that were in the process of milking were taken into account (cows in dry therapy were excluded). On the other hand, the surface of the farm destined for milk production is 80 to 300 ha (data not shown by producer), which on average by type of dairy is $121.3 \pm 117.8$ ha (Table I).

In addition, the average milk production varies depending on the number of milking cows that are on each farm. This value ranged from 80 to I,600 L/day, which in average was 5 I $5 \pm 562,3 \mathrm{~L} /$ day, according to the farm size. Milk production per cow ranges is from 3.5 to $7 \mathrm{~L}$ (data not shown by producer) which is in average $4,8 \pm 0,7 \mathrm{~L}$, according to the farm size (Table I), where only 5 farms are at or above the national average production of $4.8 \mathrm{~L} / \mathrm{cow}$ day (CONPES, 2005). Moreover, although 6 of the farms produce from 3.5 to $4.6 \mathrm{~L} /$ cow day (data not shown by producer), which is below the national average, they are above the departmental average, which is reported to be $2.97 \mathrm{~L} /$ cow day for the department of Córdoba. The variation of milk production in the studied farms in average is not very significant, although the productivity of three of the farms whose type of dairy is large and medium that average produce $7 \mathrm{~L}$ per day per cow (data not shown by producer), this is due to the good productive management implemented and the various types of production, as indicated by Guapi et al. (2017) in a study conducted in a province of Ecuador whose production rates in various types of production per cow reached average values of 6.10 to 10 , $27 \mathrm{~L} /$ cow day, figures that may be related to the use of balanced supplements, lower animal load in the prairies, the type of breed and the type of fodder, among others.

Regarding this, the cooperative has indicated that milk producers must increase the production and efficiency in the cattle herd during the shortage period by means of the genetic improvement in order to expand the production of milking cows, considering that reference countries, such as Brazil, have improved production, achieving 15 to $20 \mathrm{~L} /$ day. In order to improve the competitiveness of the milk production, the cooperative advanced an embryo transfer program by crossing the Gyr and Holstein breeds to generate "Girolando", a genetically improved breed that increases the milk production (Motta et al., 2012). This program will allow the producers to be more competitive in the milk production agribusiness. This demonstrates that the support of the cooperative allows developing actions that lead to work together to achieve improved results, instead of isolated activities, which can lead to improved results, however, with greater difficulty (Dini, 20I0).

\section{Requirements for milk producers to be considered as cooperative suppliers}

The hazards related to food safety and that take place during the food production are worldwide recognized. In this context, the food industries have an increasing interest in considering and analyzing the whole food chain in order to ensure the food safety, from the raw material to the final product (Valeeva et al., 2005). Among different food chains, the one of milk and dairy product is

Table I. Dairy type and daily production of milk from the studied farms according to the size of the milk (dairy) production

\begin{tabular}{|c|c|c|c|c|c|c|}
\hline \multirow{2}{*}{ Type of dairy } & \multirow{2}{*}{ Farms } & \multirow{2}{*}{ Dairy farm hectare } & \multirow{2}{*}{$\begin{array}{l}\text { Number of dry } \\
\text { cow therapy }\end{array}$} & \multirow{2}{*}{$\begin{array}{l}\text { Number of } \\
\text { milking cows }\end{array}$} & \multicolumn{2}{|c|}{ Production liters of milk daily } \\
\hline & & & & & by cow & total \\
\hline Big & 2 & 255 & 105 & 210 & 5.35 & $\mathrm{I}, 150$ \\
\hline Medium & 8 & 75.9 & 55.4 & 63.5 & 4.95 & 315 \\
\hline Small & I & 33 & 12 & 20 & 4 & 80 \\
\hline Avarage & & 121.3 & 172.4 & 61.8 & 4.8 & 515 \\
\hline Standard deviation & & 117.8 & 46.5 & 5 & 0.7 & 562.3 \\
\hline
\end{tabular}


considered as one of the safest. However, since milk and dairy products are widely consumed, this food chain is of special concern due to the fact that problems related to food safety in the milk chain would affect a large number of consumers. The main potential safety problems are associated to the incidence of foodborne pathogens, such as Escherichia coli, Listeria monocytogenes, Salmonella, Staphylococcus aureus, as well as the occurrence of chemical hazards, such as the presence of mycotoxins and drug residues, among others (Valeeva et al., 2005).

In this regard, one of the most important criteria in the selection of the milk producer that will supply the cooperative is to have a cold tank to ensure that the obtained milk is submitted to the proper cold chain before its processing. This aspect is fundamental to ensure raw material safety, the optimization of the process and to minimize risks that can affect the quality of the final product (pasteurized milk or dairy products). It is worth noting that only 4 dairy producers in this study are linked to the cooperative as associates, who attend the meetings regularly and have had benefits for being associated, from which they receive training, technical assistance, advice and support for the process of milk marketing.

Likewise, the cooperative values the effort that the producers make by investing in specialized equipment (mechanical equipment for the milking process and/or cold tank). It should be noted that this cooperative is one of the few companies in the entire Caribbean Region of Colombia that has set this requirement. However, despite the stimulus offered in the payment of the product, very few producers have such equipment (cold tank). In this regard, among the studied farms, only 4 owned a cold tank to store and preserve the obtained milk.

From the milk producers who did not have a cold tank, only I were in the process of installing it and 3 made an alliance with other producers who owned it to collect their milk and keeping it in the proper cold chain. The use of a cold tank is reflected positively among the farmers, as its use resulted in an increased price of the raw milk.

Similarly, only 4 of the producers had mechanical milking, from which only 2 had their complete equipment (mechanical milking and cold tank) to collect milk. Thus, these producers do not require canteens to store the milk, since it goes directly to the cold tank through a pipe system. The complete system of mechanical milking and cold tank storage contributes to minimize the microbiological risk and maintain the quality of the raw milk. In this regard, the increase in temperature and the time between the displacements of the product from the milking pens to the cooling tank can increase the mesophilic microorganisms in the milk, affecting the quality of the raw milk.

For those farmers who collect the milk in aluminum canteens (7), the risk of contamination is imminent. In addition, 2 of these producers also use plastic canteens (Meneses, et al. 20I5), not following what is stipulated by the Colombian Agricultural Institute [ICA] (20II). In this regard, the ICA has indicated that the milk must be received and stored in aluminum or stainless-steel containers, never in plastic buckets which may contain substances that might migrate from the polymer to the milk and contaminate it.

\section{Market and price of the raw milk}

Usually the cooperative makes an analysis of the milk market to determine the current price of the raw milk. This price is set according to the quality payment system, regulated according to Minagricultura (20I2). Likewise, the quality payment system seeks to motivate the farmers to increase the production of raw milk, especially during summer time, when the milk production is low, with a bonus payment.

However, the overproduction of raw milk results in a considerable fall of prices in the market. Therefore, according to the season, the cooperative might pay around US $\$ 0.48 / \mathrm{L}$ to US $\$ 0.54 / \mathrm{L}$. Other payment bonus (around the US $\$ 0.03$ ) can be done by the cooperative, paid additionally to the farmer when the milk comes from a cold tank, which allows ensuring the proper temperature to preserve the product and minimize foodborne risks (Marin et al., 2017).This bonus payment is a higher amount than what is legally established in Resolution 017 of 2012 (Minagricultura, 20I2), which is the US $\$ 0.013$ (this price is adjusted annually). Thus, the cooperative promotes the use of cooling temperatures for milk preservation. In this context, the cold tank requirement established as a mean for obtaining the bonus payment results in a motivational strategy, which results in the farm technification, ensuring the quality of collected milk and allowing meeting the Crosby quality principle, which consists on doing things correctly from the first time. Therefore, this strategy seeks the articulation of farmers and the cooperative in order to obtain better results for both actors of the milk productive chain. 
However, some other producers have indicated different prices than those aforementioned, ranging from US $\$ 0$, $32 / L$ and US $\$ 0.47 / L$, since not all the producers sell the milk to the cooperative. In this regard, some of them usually sell the milk to small pasteurizing companies and artisanal organizations, which elaborate coastal fresh cheese (known in this region of Colombia as "queso costeño"). In this regard, more than half of the farms (6) indicated a price which is not competitive, 4 of this producers commercialize their product in the informal market (figure la). From the size of the dairy, it can be observed that in average the big farms are characterized by having a more competitive price (figure Ib) above the average price US $\$ 0.39 / \mathrm{L}$. Moreover, the payment system used in any of these articulations does not consider the bonus payment regarding the milk quality payment system, being this the result of the product commercialization in the informal market or due to not making negotiations with companies that meet this buying criterion.

Few dairy farms (4/II) that produce milk in the informal market (Figure la), this is partly due to having a direct relationship with the market, be it the final consumer or small distributor to reduce the level of intermediaries and thus control the negotiation price, tax evasion, in addition to lower investment in their farms in accordance with the demands made by the legalized industries such as good practices and the use of the cold tank (Bankuti \& Souza,
2006), added to the non-compliance with the technical regulations in force to the dairy market (Meneses et al., 2015).

Therefore, it is necessary that producers of dairy farms are articulated within a value chain that strengthens milk production in the Córdoba region (Kilelu et al 2017) either vertically or horizontally and thus achieving greater competitiveness of the product in the market (Beber et al., 2019).

\section{Raw milk quality analysis}

Another requirement implemented by the cooperative to ensure milk quality is the analysis of raw milk during cold storage and at the reception. This analysis is done by a certified laboratory according to the regulations of the ICA. This analysis includes the determination of fat and protein content, the presence of microorganisms (measured as colony forming units), total solids, acidity and antibiotics (Minagricultura, 20I2).

If the milk has any abnormality, the cooperative investigates the origin of the milk, since sometimes one cold tank might store milk from several farms. Then, the cooperative identifies the cause of the problem to take corrective actions. When there are unfavorable results in the milk quality and there is a controversy between the parties (cooperative and farmers), the cooperative allows the farmer to corroborate this result in another laboratory; which contributes to a good relationship in the negotiation and fidelity of the farmer with the cooperative

Figure I. Price of the milk sold by farm (a) and in average according to the farm's size (b) $* F=$ formal, $I=$ informal, $B=$ big, $M=$ medium, $S=$ small

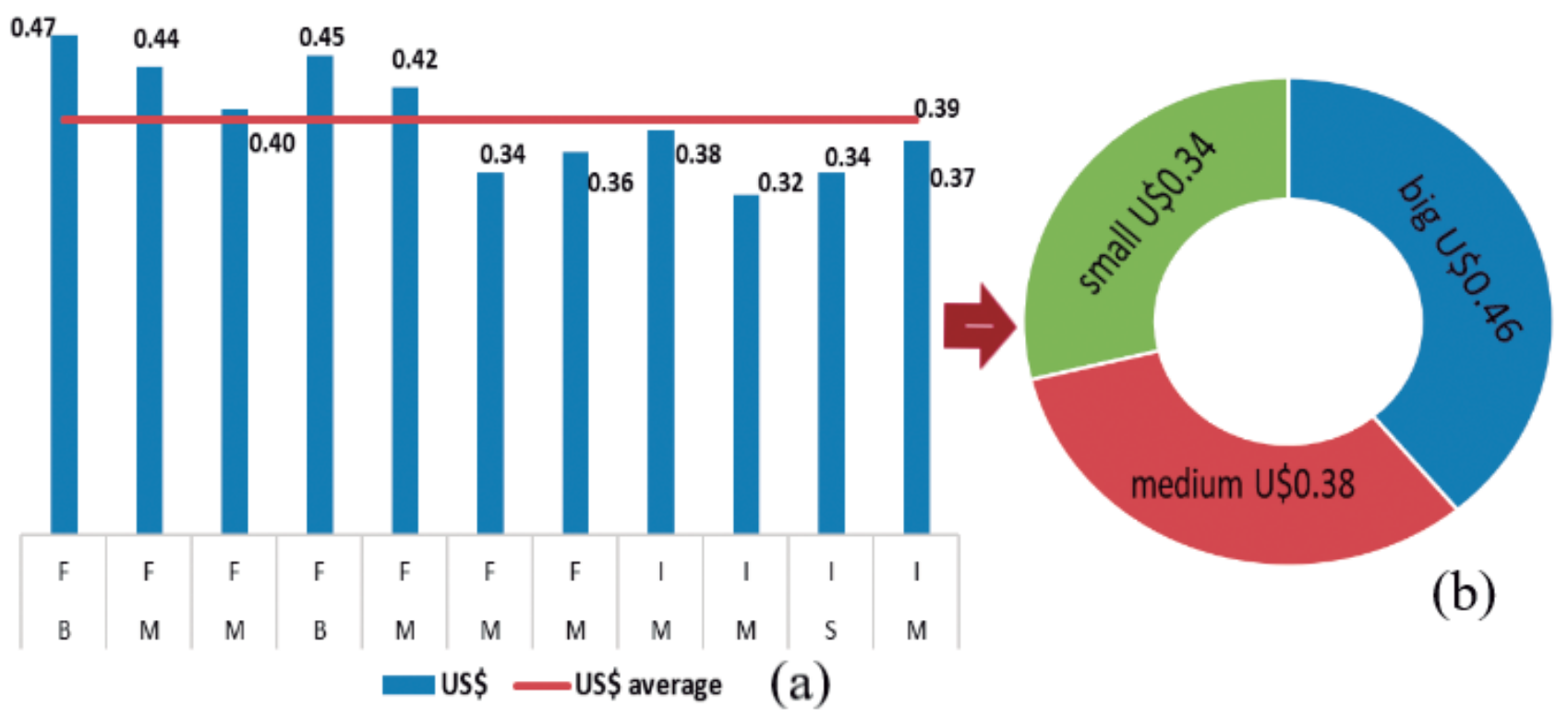


(CIAT, 2007). The time that the cooperative keeps the milk without decreasing the quality depends on the milk and its heating process (between 65 and $68{ }^{\circ} \mathrm{C}$ ), which can last from three to four days; if it is pasteurized eight days. If the milk is pre-condensed it allows them to save transport because they minimize the volume of this one to take it to other milk processors.

\section{Limitations of the cooperative- milk producer's articulation}

The agreements made with the producers are verbal and indefinite. Because milk production varies on farms, the producers do not have an established fixed volume of milk for delivery. The most frequent limitation of the articulation cooperative-milk producer is the quality of the milk and the delivery schedule, which are resolved in an agile way.

\section{Raw milk transportation}

The milk transport is ensured by an indefinite contract that the cooperative usually make with a milk transporting service. This contract includes specific clauses such as compliance, proper management, and good hygiene practices, among others. This allows minimizing the maintenance expenses and labor cost, among another factor that might affect the final price of milk. The cold tanks for transportation are owned by the cooperative. This facilitates ensuring proper cleaning and disinfection of cold tanks. Milk reception hours range from 15 hours to 18 hours. Most of the milk producers are located relatively close, which allows the quick milk collecting process and minimize the risk due to temperature variation. Some drawbacks of this process include the volume delivered and the watering of the milk; however, this has been solved.

\section{Advantages for milk producers}

According to Abecassis et al. (2017), there are four benefits to those organizations which belong to a food supply chain, in a way or articulation: I) the process of food delivery, in all stages, is done with efficiency since there is a coordination of raw material production that meets the requirements of the processing conditions and to finally develop a product which meets consumer's expectations (in terms of sensorial characteristics, nutritional value, and safety); 2) allows adapt and generate quick responses to always changing demands, trends and preferences of consumers; 3) allows fair and transparent in transactions and logistics; and 4) allows to strengthen the articulation of the different stakeholders in the food chain since innovations can be done in the direction of "farm to fork" and vice versa.

In this study, the benefits offered by the cooperative to its milk producers associates are: a) the transfer of knowledge and capacity building through training; as well as $b$ ) lectures given by pharmaceutical laboratories; c) arrangements with professionals or institutions in charge of advising regarding the technification (technology adoption) process of milk farms; d) In this context, this process enables milk producers to enter the financial sector for the acquisition of cold tanks or equipment that they require, by means of credits and periodical visits by agricultural and veterinary technologists to monitor production and ensure raw milk quality. All these benefits allow maintaining and strengthening the cooperative-milk farmer's articulation and their relationships based on trust in a win-win relationship.

In this context, according to Janssen and Swinnen (2019), the process of technology adoption is a determinant factor for improving living conditions of small farmers in developing countries, achieving poverty reduction and rural development.

However, although the stated benefits, there was a small number of milk producers surveyed (4) that were associated to the cooperative. In this regard, the articulation of the cooperative with milk producers has been difficult to promote in Colombia (García, 20I4). Moreover, at a regional level, there is a lack of associative culture, which plays a determinant role limiting the productive strengthening strategies for the milk production sector.

Similarly, Janssen and Swinnen (2019) have indicated that regardless of an increased consumption of milk and milk products, the role of the value chain was not significant to the process of technology adoption. This might be associated with a considerable investment by small farmers to improve the production of the raw material (milk) which results in a limited profit in order to satisfy quality and private standards.

\section{Education oriented to milk producers}

Another identified drawback is concerning the training and building capacity process. In this regard, the milk producers said that their attendance to these activities is variable. Less than half of the surveyed milk producers (5) do it regularly (monthly and quarterly), while the rest of 
the milk producers do it semiannual and annual. As a consequence, milk producers updating and implementation of new technology are limited.

Despite this, all the milk producers surveyed have veterinary technical assistance, I have frequent technical advice because the farm owner is a Veterinarian and Zootechnician, while others pay this service biweekly, monthly and quarterly.

As a business culture, the cooperative promotes the use of the National Bovine Cattle Identification and Information System (SINIGÁN - Sistema Nacional de Identificación e Información del Ganado Bovino) software in order to improve the administrative management and negotiations activities with producers based on a win-win relationship. However, the implementation of this type of tools by the producers is moderate, since less than half (5) acquired this type of software due to lack of computer skills.

However, the majority (I0) of milk producers are willing to make commitments to sell their milk safely; as well as to participate in processes of linkage (production, transportation, market, and processing) of milk; which is a good indicator to improve milk production in the region of Córdoba.

Finally, it should be noted that the articulation of milk producers and the cooperative is based on a culture of solidarity (Cuadros et al., 2007); however, in this research few farmers were actually linked to the cooperative or had a commercial link with formal companies for milk processing or transformation.According to CIAT (2007), this limits vertical alliances, which results in a limited participation in the milk value chain. Therefore, more interaction between milk producers and cooperatives should be promoted in order to obtain benefits such as educational training, technical assistance, safe market for their milk, better price, credits in agricultural stores, management of procedures before financial institutions, among other advantages; which helps small milk producers to make improvements in their production system in a sustainable manner.

\section{Conclusions}

Although not all producers of the dairy farms studied are linked to the cooperative, they have a good relationship and help each other through strategic alliances to obtain better benefits in their production and in the sale of milk.
From most commercialize milk in the formal market, only 4 farms sell their product to the informal market, ignoring the advantages of being involved in a value chain so that in a certain way, a better articulation between the actors and a better competitiveness is achieved.

The low educational level of the orders of the farms producing milk of studio, can influence in a certain way that the articulation between the producers and the cooperative is not achieved effectively, because there is a risk that those who are linked to this, do not participate in the benefits or the proper interpretation of the advice offered, among others, is not achieved. On the other hand, the producers that are not linked to the cooperative will have low influence of the managers so that they are linked as associates in a short term that also allows them to enjoy the benefits.

As for the articulation between the dairy producers linked to the cooperative, it is evident that the good relationship based on trust, gives freedom to the associated producer to verify in another laboratory if the results of the analyzed milk sample were not satisfactory, they have technical assistance for the improvement of production and compliance with the quality parameters, which is achieved with the exchange of services and the standardization of processes taking into account good dairy practices.

Moreover, the association of milk producers with the cooperative allows a better participation in a demanding market determined by quality criteria. The requirements necessary to ensure milk quality include the accessibility to a cold tank. The milk producers benefit due to a better price paid for raw milk. Thus, these actions contribute to achieving a better participation in the milk production chain.

Finally, this will be possible only with the combined effort of all actors in the productive chain which will result in more competitiveness and therefore, more sustainability for the milk producers.

\section{Acknowledgments}

The authors express their gratitude to all the stakeholders who participated in this study.

\section{Conflicts of interest}

The authors agree with the publication of this article and declare that there are no conflicts of interest that affect the results. 


\section{References}

Abecassis, J., Cuq, B., Escudier, J.-L., Garric, G., Kondjoyan, A., Planchot, V., Salmon, J-M., \& De Vries, H. (20I7). Food chains: The cradle for scientific ideas and the target for technological innovations. Innovative Food Science \& Emerging Technologies, 46, 7-17. http://dx.doi.org//0.1016/j. ifset.2017.09.0II

Albor, C. (20I I). The debate about the commercialization of raw milk intensifies. Se intensifica el debate por la comercialización de la leche cruda. Colombia: El Heraldo. Retrieved from http://www.elheraldo.co/economia/se-intensifica-el-debate-por-la-comercializacion-de-la-leche-cruda-27। 74

Alburquerque, F., \& Dini, M. (2008). Learning guide on productive integration and territorial economic development. Guía de aprendizaje sobre integración productiva y desarrollo económico territorial. Sevilla: Universidad de Sevilla, Instituto de Desarrollo Regional.

Asociación Colombiana de Procesadores de Leche [ASOLECHE]. (2010). Agreement of competitiveness of the Colombian dairy chain. Acuerdo de competitividad de la cadena láctea colombiana. Colombia: Colombian Association of Milk Processors. Retrieved from http://www.asoleche. org/index.php?...339\%3Aacuerdocadena2010

Bankuti, F. I., \& Souza Filho, H. M. D. (2006). Informality in agroindustrial systems: the cases of beef and milk agroindustrial systems. A informalidade em sistemas agroindustriais: os casos dos sistemas agroindustriais da carne bovina e do leite. Agronegócios: gestão e inovação. São Paulo: Saraiva, I, 3-345.

Beber, C. L., Carpio, A. F. R., Almadani, M. I., \& Theuvsen, L. (2019). Dairy supply chain in Southern Brazil: barriers to competitiveness. International Food and Agribusiness Management Review, 22(5), 65 I-673.

Casal, J., \& Mateu, E. (2003). Types of Sampling. Tipos de Muestreo. Revista de Epidemiología y Medicina Preventiva, I, 3-7.

Centro Internacional de Agricultura Tropical [CIAT]. (2007). Mechanisms of articulation of small rural producers to private companies in Colombia: Presentation case study. Mecanismos de articulación de pequeños productores rurales a empresas privadas en Colombia: Presentación estudio de caso. Retrieved from http://www.bibliotecavirtual.info/wp-content/ uploads/2012/09/articulacion-pequenos-productoresempresa-privada-colombia.pdf

Craviotti, C. (2019). Multi-scale dynamics and globalized companies in the Argentine dairy activity. Dinámicas multiescalares y empresas globalizadas en la actividad láctea argentina. Revista Mexicana de Sociología, 8I (4).
Consejo Nacional de Política Económica y Social [CONPES]. (2005). Consolidation of health and safety policy for the dairy and meat chains. Consolidación de la política sanitaria y de inocuidad para las cadenas láctea y cárnica. Colombia: $\mathrm{Na}$ tional Council of Economic and Social Policy. Retrieved from http://www.minambiente.gov.co/images/normativa/ conpes/2005/Conpes_3376_2005.pdf 2005.

Cuadros, M. D. P. J., Bautista, M. C., \& Arias, A. B. (2007). Tenyear National Education Plan for the solidarity economy sector: Solidarity with education, strategy towards competitiveness. Plan Nacional decenal de educación para el sector de la economía solidaria: Solidaridad con educación, estrategia hacia la competitividad. Colombia: Universidad Cooperativa de Colombia.

De Sousa, D. N., dos Santos Macedo, A., Milagres, C. S. F., \& Costa, M. S. (2017). The challenges of cooperatives in the agro-industrial system of dairy food chain. Os desafios das cooperativas no sistema agroindustrial da cadeia produtiva do leite. Revista de Gestão e Organizações Cooperativas, 4(8), I23- I 40.

Dini, M. (2010). Competitiveness, business networks and productive development. Competitividad, redes empresariales y desarrollo productivo. Santiago de Chile: ILPES-CEPAL.

Dini, M., Mazzonis, D., \& Pérez, R. (2006). Collective actions, generation of trust and cooperation for competitiveness. Acciones colectivas, generación de confianza y cooperación para la competitividad. Washington DC: FOMIN.

Ferraro, C. (2010). Clusters y políticas de articulación productiva en América Latina. Santiago de Chile: CEPAL, ONU and FUNDES.

García, S. (2014). Associativity, key to improving dairies but not the only thing. Asociatividad, clave para mejorar lecherías pero no lo único. Colombia: Contexto ganadero. Retrieved from http://www.fedegan.org.co/noticias/informe-asociatividad-clave-para-mejorar-lecherias-pero-no-lo-unico

Govindan, K. (2018). Sustainable consumption and production in the food supply chain: A conceptual framework. International Journal of Production Economics, 195, 41 9-431. http://dx.doi.org//0.1016/j.ijpe.2017.03.003

Guapi, G., Adolfo, R., Masaquiza Moposita, D., \& Curbelo Rodríguez, L. M. (2017). Characterization of Dairy Production Systems in Terms of Mountain Químiag Parish, Chimborazo Province, Ecuador. Caracterización de sistemas productivos lecheros en condiciones de montaña, Parroquia Químiag, Provincia Chimborazo, Ecuador. Revista de producción animal, 29(2), I4-24. 
Instituto Colombiano Agropecuario [ICA]. (20I I). Good Livestock Practices in Milk Production. Las Buenas Prácticas Ganaderas en la Producción de Leche. Colombia.

Janssen, E., \& Swinnen, J. (2019). Technology adoption and value chains in developing countries: Evidence from dairy in India. Food Policy, 83, 327-336. http://doi.org//0.1016/j. foodpol.2017.08.005

Kilelu, C.W., Klerkx, L., \& Leeuwis, C. (2017). Supporting smaIlholder commercialisation by enhancing integrated coordination in agrifood value chains: Experiences with dairy hubs in Kenya. Experimental Agriculture, 53(2), 269-287.

López, K., \& Peña, J. (20I6). The use of benchmarking theory as a comparative model for the strategic plan in SMEs in the dairy sector in the municipality of San Juan de Pasto 2014-2019. La utilización de la teoría de benchmarking como modelo comparativo para el plan estratégico en las pymes del sector lácteo en el municipio de San Juan de Pasto 20I4-2019. Tendencias, 17(I), 56-72.

Marín, A.L.; Arredondo, B.J.; Hernandez, H.D. (2017). Good livestock practices in dairy herds of Santa Rosa de Cabal, Risaralda, Colombia. Buenas prácticas ganaderas en hatos lecheros de Santa Rosa de Cabal, Risaralda, Colombia. Revista Colombiana de Ciencias Animales., 9(Supl):67-75.

Meneses, R. M., Estrada, D. M., Chantre, C. A., \& Lopez, F. J. (2015). Characterization in the informal chain of raw milk in the municipality of Popayán. Caracterización en la cadena informal de la leche cruda en el municipio de Popayán. Biotecnología en el sector agropecuario y agroindustrial, |3(2), | 30-| 39. http://dx.doi.org/| 0. | 8684/BSAA(|3) |30139

Ministerio de Agricultura y Desarrollo Rural [Minagricultura]. (2010). National Agricultural Survey-ENA 2009: Estimates of the Colombian agricultural, fish farming and forestry activity. Encuesta Nacional Agropecuaria-ENA 2009: Estimaciones de la actividad agropecuaria, piscicola y forestal colombiana. Colombia: Ministry of Agriculture and Rural Development. Retrieved from https://datoscede.uniandes.edu.co/datoscede/anexo/materialrelacionado/l be_Metodologia_y_ resultados_ENA_2009.pdf

Minagricultura. (2012). Resolution 000017 of 2012. By which the system of payment of raw milk to the supplier is established. Resolución 000017 de 2012. Por el cual se establece el sistema de pago de la leche cruda al proveedor. Colombia: Ministry of Agriculture and Rural Development. Retrieved from https://www.minagricultura.gov.co/ ministerio/direcciones/Documents/d.angie/Res $\% 20 \% 20$ 0000I7\%20de\%2020I2.pdf
Minagricultura. (2015). Milk and dairy products food chain information. Información de la cadena láctea. Colombia: Ministry of Agriculture and Rural Development.

Motta, P. A. D., Rivera, L. G. C., Mariño, A. A., \& Lizcano, E. P. (20I2). Productive and reproductive performance of $\mathrm{FI}$ Gyr x Holstein cows in Colombian warm climate. Desempeño productivo y reproductivo de vacas $\mathrm{FI}$ Gyr $\mathrm{x}$ Holstein en clima cálido colombiano. Revista Veterinaria $y$ Zootecnia, 6(I), 17-23.

Ministerio de la Protección Social [Minsalud]. (20I I). Ordinance "By which the requirements for the marketing of raw milk for direct human consumption in the national territory are indicated". Decreto I 880 "Por el cual se señalan los requisitos para la comercialización de leche cruda para consumo humano directo en el territorio nacional". Colombia: Ministry of social protection. Retrieved from https://www.google. com/url?sa=t\&rct=j\&q=\&esrc=s\&source=web\&cd $=\mid$ \&ca $\mathrm{d}=$ rja\&uact=8\&ved=0ahUKEwiWk4y62vjVAhXGj I QKH d-xBMoQFggIMAA\&url=https\%3A\%2F\%2Fwww.invima. gov.co\%2Fdecretos-alimentos\%2Fdecreto-no- I880-27may-de-20I I-pdf\%2Fdownload.html\&usg=AFQjCNHIb UpQ5YJ9WJzTdNO69CJnIPaTPw

Porter, M. (2003). Be competitive: new contributions and conclusions. Ser competitivo: nuevas aportaciones y conclusiones. Bilbao: Ediciones Deusto.

Porter, M. E. (1998). Clusters and the New Economics of Competition. Harvard Business Review, 76(6), 77-90.

Tordecilla-Madera, R., Polo, A., Muñoz, D., \& González-Rodríguez, L. (2017). A robust design for a Colombian dairy cooperative's milk storage and refrigeration logistics system using binary programming. International Journal of Production Economics, I83(Part C), 7 10-720. http://doi. org/10.1016/j.jpe.2016.09.019

Valeeva, N. I., Meuwissen, M. P. M., Oude Lansink, A. G. J. M., \& Huirne, R. B. M. (2005). Improving food safety within the dairy chain: An application of conjoint analysis. Journal of Dairy Science, 88(4), 160I-I6I2. http://dx.doi. org/I0.3 I68/jds.S0022-0302(05)72829-0

Vera, G., \& Ganga, C. (2007). Industrial clusters: conceptual precision and theoretical development. Los clusters industriales: precisión conceptual y desarrollo teórico. Cuadernos de Administración, 20(33), 303-322.

Zylbersztajn, D. (1994). Cooperative Organization: Challenges and Tendencies. Organização de cooperativas: desafios e tendências. Revista de Administração, 29(3), 23-32. 